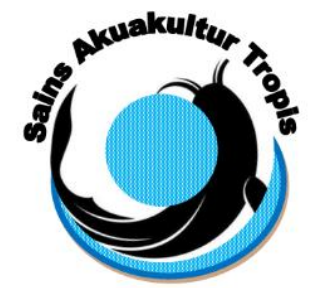

\author{
Jurnal Sains Akuakultur Tropis \\ Departemen Akuakultur \\ Fakultas Perikanan dan IImu Kelautan - Universitas Diponegoro \\ JI. Prof. Soedarto, SH, Tembalang, Semarang 50275 \\ Telp. (024) 7474698, Fax.: (024) 7474698
}

Email: sainsakuakulturtropis@gmail.com, sainsakuakulturtropis@undip.ac.id

\title{
PERFORMA PERTUMBUHAN IKAN KAKAP PUTIH (Lates calcarifer Bloch, 1790) YANG DIBUDIDAYAKAN DALAM SISTEM KERAMBA JARING APUNG (KJA)
}

Growth Performance of the Seabass (Lates calcarifer Bloch, 1790) using the Floating Net Cages System

\author{
Seto Windarto*), Sri Hastuti, Subandiyono, Ristiawan Agung Nugroho, Sarjito \\ Departemen Akuakultur, \\ Fakultas Perikanan dan Ilmu Kelautan, \\ J1. Prof. Soedarto, SH, Tembalang, Semarang, Jawa Tengah -50275 , Telp/Fax. +62247474698 \\ * Corresponding author: seto.sidhartawan@gmail.com
}

\begin{abstract}
ABSTRAK
Ikan kakap putih (Lates calcarifer) merupakan salah satu komoditas budidaya laut unggulan di Indonesia, karena memiliki pertumbuhan yang relatif cepat, kelangsungan hidup dapat mencapai $86 \%$, dan mudah menyesuaikan diri dengan lingkungan budidaya. Kegiatan budidaya kakap putih di Indonesia saat ini masih belum banyak berkembang, salah satu faktor yang menghambat kegiatan pembesaran kakap putih di Indonesia adalah masih sulitnya pengadaan pakan rucah secara berkelanjutan dalam jumlah yang cukup. Salah satu upaya kegiatan pembesaran ikan kakap putih yang dapat dilakukan adalah dengan media keramba jaring apung (KJA) dan penggunaan pellet sebagai ganti pakan rucah. Penelitian ini bertujuan untuk mengetahui performa pertumbuhan ikan kakap putih (Lates calcarifer) yang dibudidayakan dengan sistem keramba jaring apung (KJA). Hasil dari pengamatan performa pertumbuhan ikan kakap putih yang dibudidayakan dengan sistem KJA adalah nilai SGR $0,28 \%$ /hari, nilai pertumbuhan bobot mutlak $47 \mathrm{~g}$, dan nilai kelulushidupan $82,5 \%$. Hasil pengukuran parameter kualitas air meliputi salinitas berkisar 30-33\%, DO antara 4,89 hingga 5,89 mg/L, suhu antara 29 hingga $29,9^{\circ} \mathrm{C}$, pH antara 7 hingga 7,8, kecerahan antara 9 hingga $9,5 \mathrm{~m}$.
\end{abstract}

Kata kunci: Kakap putih, KJA, pertumbuhan, kelulushidupan

\section{ABSTRACT}

Lates calcarifer is one of the leading marine aquaculture commodities in Indonesia, because it has relatively fast growth, survival rate about $86 \%$, and easily adapt to the environment. Seabass cultivation activities in Indonesia have not yet developed, one of the factors that inhibit seabass enlargement activities in Indonesia is the difficulty of procuring continuous trash fish in sufficient quantities. One effort to enlarge the seabass that can be done is by floating net cage (KJA) system and using pellets instead of trash fish. This study aims to determine the growth performance of seabass (Lates calcarifer) which is cultivated with floating net cage (KJA) system. The result of observing the growth performance of cultivated seabass using the KJA system including absolute weight of 0,28\% / day, specific growth rate of $47 \mathrm{~g}$, and survival rate of $82.5 \%$. The results of measurements of water quality parameters include salinity ranging from 30-33\%, DO between 4.89-5.89 $\mathrm{mg} / \mathrm{L}$, temperatures between 29-29.9 $9^{\circ}$, pH between 7-7.8, and brightness between 9-9.5 $\mathrm{m}$.

Keywords: Lates calcalifer, floating cages, Growth, Survival Rate

Article Received: 18-01-2019; Accepted: 28-02-2019

\section{PENDAHULUAN}

Ikan kakap putih (Lates calcarifer) merupakan salah satu komoditas budidaya laut unggulan di Indonesia, karena memiliki pertumbuhan yang relatif cepat. Menurut Rayes et al., (2013), pertumbuhan kakap putih dapat mencapai laju pertumbuhan harian sebesar 0,51\%/hari. Kelangsungan hidup dapat mencapai $86 \%$, dan mudah menyesuaikan diri dengan lingkungan budidaya (relatif mudah dibudidayakan). 
Kakap putih merupakan spesies ikan budidaya di Indonesia yang memiliki permintaan pasar yang terus meningkat. Permintaan impor pada tahun 2012 negara di Eropa (Italia, Spanyol, dan Prancis) mencapai 14.285 ton, dan pada tahun 2014 meningkat menjadi 18.572 ton (Hardianti et al., 2016). Menurut Purba et al., (2016), kakap putih merupakan salah satu jenis ikan air laut yang memiliki kandungan omega-3, kandungan protein sekitar 20\%, dan mempunyai kadar lemak sebesar 5\%.

Kegiatan budidaya kakap putih di Indonesia saat ini masih belum banyak berkembang, sedangkan di beberapa negara Asia Tenggara (Malaysia, Thailand dan Singapura) budidaya ikan kakap dalam keramba jaring apung di laut telah berkembang. Salah satu faktor yang menghambat kegiatan pembesaran kakap putih di Indonesia adalah masih sulitnya pengadaan pakan rucah secara kontinyu dalam jumlah yang cukup. Selain itu kurangnya keahlian masyarakat dalam budidaya ikan kakap putih. Salah satu upaya kegiatan pembesaran ikan kakap putih dapat dilakukan pada media keramba jaring apung (KJA) dan sebagai ganti pakan rucah dapat menggunakan pelet. Selain itu panduan teknis yang telah dikembangkan dapat digunakan untuk memperoleh hasil suatu kegiatan budidaya yang berkelanjutan (Badrudin et al., 2015).

Penelitian ini bertujuan untuk mengetahui performa pertumbuhan ikan kakap putih (Lates calcarifer) yang dibudidayakan dalam sistem keramba jaring apung (KJA). Penelitian ini dilaksanakan pada bulan Desember 2017 - Januari 2018 di Lampung.

\section{MATERI DAN METODE}

Hewan yang digunakan adalah ikan kakap putih (Lates calcarifer). Pakan yang digunakan selama proses pembesaran ikan kakap adalah pakan pelet merk dagang "Megami" dengan ukuran GR-7 dengan kadar protein $46 \%$ yang diberikan setiap 2 kali dalam satu hari secara at satiation.

Alat yang digunakan dalam penelitian antara lain keramba jaring apung sebagai wadah pembesaran kakap putih, seser sebagai alat untuk mengambil ikan, size cover sebagai penutup keramba jaring, timbangan sebagai alat untuk mengukur bobot, water quality control (WQC) sebagai alat untuk mengukur kualitas air, alat tulis sebagai alat untuk mencatat, dan kamera sebagai alat untuk dokumentasi.

Metode yang digunakan dalam penelitian ini adalah eksploratif. Data yang diperoleh dianalisis secara deskriptif. Metode analisis diskriftif merupakan metode yang digunakan untuk menganalisis data dengan cara mendeskripsikan atau menggambarkan data yang telah terkumpul. Jenis data yang digunakan dalam penelitian ini adalah data kuantitatif yang dinyatakan dalam angka dan dianalisis dengan teknik statistik (Sugiyono, 2010).

\section{Pengumpulan Data}

Variabel yang diukur pada penelitian ini meliputi bobot mutlak ikan kakap putih, laju pertumbuhan spesifik (SGR) ikan kakap putih, kelulushidupan (SR) ikan kakap putih, efisisensi pemberian pakan, dan kualitas air. Data kualitas air yang diukur meliputi DO, suhu, $\mathrm{pH}$, dan salinitas, dan kecerahan.

\section{Pertumbuhan}

\section{a. Bobot mutlak}

Menurut (Effendi, 1997) pertumbuhan bobot udang windu (P. monodon) dapat dihitung dengan menggunakan rumus :

$$
\mathrm{W}=\mathrm{Wt}-\mathrm{Wo}
$$

keterangan: $\quad \mathrm{W} \quad=$ laju pertumbuhan relatif $(\mathrm{g})$

$\mathrm{W}_{\mathrm{t}} \quad=$ bobot tubuh rata-rata akhir pemeliharaan $(\mathrm{g})$

$\mathrm{W}_{\mathrm{o}} \quad=$ bobot tubuh rata-rata awal pemeliharaan $(\mathrm{g})$

\section{b. Laju pertumbuhan spesifik/Specific Growth Rate (SGR)}

Penghitungan laju pertumbuhan spesifik (SGR) diukur dengan melakukan pengambilan dan pengukuran ikan pada saat awal dan akhir melakukan penelitian . Pengkuran laju pertumbuhan spesifik yakni menggunakan rumus yang dikemukakan oleh Jaya et al., (2013), sebagai berikut :

$$
\mathrm{SGR}=\frac{\ln W \mathrm{t}-\ln W o}{\mathrm{t}} \times 100 \%
$$

keterangan:

$$
\begin{array}{ll}
\mathrm{SGR} & =\text { Laju pertumbuhan spesifik (\%) } \\
\mathrm{Wt} & =\text { Bobot rata-rata di akhir pemeliharaan (ekor) } \\
\mathrm{Wo} & =\text { Bobot rata-rata di awal pemeliharaan (ekor) } \\
\mathrm{t} & =\text { Lama waktu pemeliharaan (hari) }
\end{array}
$$




\section{Kelulushidupan/Survival Rate (SR)}

Menurut Effendi (2003), kelulushidupan merupakan prosentase kelulushidupan kultivan yang dapat dihitung dengan rumus sebagai berikut:

$\begin{array}{lll} & & \mathrm{SR}=\frac{\mathrm{Nt}}{\mathrm{No}} \times 100 \% \\ \text { keterangan : } & \mathrm{SR} & =\text { kelulushidupan }(\%) \\ & \mathrm{N}_{\mathrm{t}} & =\text { jumlah ikan pada akhir pemeliharaan (ekor) } \\ & \mathrm{N}_{\mathrm{o}} & =\text { jumlah ikan pada awal pemeliharaan (ekor) }\end{array}$

\section{Efisiensi pemanfaatan pakan}

Efisiensi pemanfaatan pakan (EPP) dapat dihitung menurut Djajasewaka (1985) dalam Iskandar dan Elrifadah (2015), dengan rumus sebagai berikut:

$\begin{array}{ll} & \mathrm{EPP}=\frac{(\mathrm{Wt}+\mathrm{D})-\mathrm{Wo}}{\mathrm{F}} \times 100 \% \\ & \text { keterangan: } \\ \mathrm{EPP} & =\text { Feed Convertion Ratio } \\ \mathrm{Wo} & =\text { Bobot hewan uji pada awal penelitian } \\ \mathrm{Wt} & =\text { Bobot hewan uji pada akhir penelitian } \\ \mathrm{D} & =\text { Jumlah ikan yang mati } \\ \mathrm{F} & =\text { Jumlah pakan yang dikonsumsi }\end{array}$

\section{Kualitas air}

Kualitas air yang diukur selama penelitian dengan mengukur tingkat keasaman $(\mathrm{pH})$ air, salinitas, dan oksigen terlarut atau dissolved oxygen/DO $(\mathrm{mg} / \mathrm{L})$ dan suhu $\left({ }^{\circ} \mathrm{C}\right)$ dan tingkat kecerahan.

\section{Analisis Data}

Analisis data yang dilakukan meliputi nilai bobot, laju pertumbuhan relatif (RGR), laju pertumbuhan harian (SGR), kelulushidupan (SR) dan kualitas air. Data-data tersebut dianalisis secara deskriptif.

\section{HASIL DAN PEMBAHASAN}

Berdasarkan hasil penelitian yang dilakukan selama 32 hari tentang pembesaran ikan kakap putih yang dibudidayakan dengan sistem keramba jaring apung di perairan Lampung, dengan pemberian pakan berupa pellet kadar protein $46 \%$ diperoleh hasil nilai laju pertumbuhan hariannya adalah sekitar $0,28 \%$ /hari, sedangkan untuk nilai pertumbuhan bobot mutlak pada pembesaran kakap putih ini adalah sebesar $47 \mathrm{~g}$, hal tersebut tegolong mendekati baik. Hal ini diperkuat oleh Novriadi et al., (2014), yang menyatakan bahwa laju pertumbuhan spesifik dan pertumbuhan bobok mutlak kakap putih pada saat pembesaran yang baik yakni $0,51 \%$ /hari dan berkisar antara 50-60 g. Selain itu, nilai ini dapat dikatakan baik apabila dibandingkan dengan penelitian yang dilakukan oleh Yaqin et al., (2018) yang menggunakan sistem budidaya yang sama dengan pakan berbeda (kandungan protein $40 \%$ ) menghasilkan bobot mutlak sebesar 37,82 $\pm 9,61 \mathrm{~g}$ dan laju pertumbuhan harian sebesar 0,63 $\pm 0,16 \mathrm{~g} / \mathrm{hari}$.

Faktor yang memengaruhi pertumbuhan dibagi menjadi dua bagian besar yaitu faktor dalam dan faktor luar. Faktor dalam meliputi faktor yang memengaruhi pertumbuhan dari, seperti keturunan, sex, umur, parasit, dan penyakit. Sedangkan faktor luar yang memengaruhi pertumbuhan antara lain jumlah dan ukuran makanan yang tersedia, suhu, oksigen terlarut, dan faktor kualitas air. Faktor ketersedian makanan sangat berperan dalam proses pertumbuhan. Pertama memanfaatkan makanan untuk memelihara tubuh dan menggant sel-sel tubuh yang rusak, kemudian kelebihan makanan yang tersisa baru dimanfaatkan untuk pertumbuhan. Menurut Akbar et al., (2012), banyak faktor yang memengaruhi pertumbuhan kultivan baik dari genetik maupun dari asupan nutisi yang diberi. Komposisi pakan, cara pemberian pakan, waktu pemberian pakan, genetik dan kondisi lingkungan adalah merupakan faktor yang menentukan terhadap pertumbuhan dan daya tahan hidup terhadap penyakit dalam suatu sistem akuakultur. Perbedaan pertumbuhan ini juga diduga akibat dari jenis pakan dan jumlah protein yang terkandung dalam pakan. Hepher (1988) menjelaskan bahwa sebagian besar ikan memerlukan protein 35-45\% dalam pakannya. Mengamati kandungan pakan berupa pellet sebesar 28-30\% diduga menyebabkan lambatnya pertumbuhan dibandingkan pertumbuhan ikan kakap putih dengan pemberian pakan dengan kandungan protein yang lebih tinggi. Menurut Chen dan Tsai (1994), kekurangan protein dalam pakan akan mengakibatkan perlambatan pertumbuhan akibat adanya perombakan cadangan protein dalam tubuh ikan menjadi energi melalui peristiwa deaminasi.

Nilai kelulushidupan (SR) pada ikan kakap putih (L. calcarifer) dapat dihitung dengan cara menghitung jumlah awal pada saat pengamatan dan menghitung jumlah akhir pada saat pengamatan. Tingkat kelulushidupan 
dimaksudkan untuk mengetahui jumlah yang mati selama masa pemeliharaan yang berpengaruh terhadap hasil produksi selama masa pembesaran. Pengamatan tingkat kelulushidupan kakap putih dilakukan pada saat awal pengamatan yakni 270 ekor dan pada akhir pengamatan berkurang menjadi 223 ekor. Pengamatan dilakukan selama 32 hari. Nilai kelulushidupan apabila diasumsikan didapatkan hasil 82.5\% dan termasuk kedalam kategori mendekati baik. Menurut Yasin et al., (2018) ikan kakap putih yang dibudidayakan dengan pemberian pakan dengan kadar protein sebesar 40\% memiliki nilai kelulushidupan sebesar $28.89 \pm 16.36 \%$. Menurut Novriadi et al., (2012), nilai kelulushidupan kakap putih pada saat pembesaran yakni berada pada nilai $86 \%$ dan ditambahkan oleh Cremer et al., (2001) nilai kelulushidupan ikan kakap putih berkisar 89,3\%. Kelulushidupan dapat digunakan sebagai parameter untuk mengetahui toleransi dan kemampuan hidup dalam suatu populasi dengan melihat mortalitas.

Efisiensi pakan merupakan banyaknya pakan yang termakan oleh ikan yang kemudian masuk dalam sistem pencernaan ikan untuk melangsungkan metabolisme dalam tubuh dan dimanfaatkan untuk pertumbuhan Nilai efisiensi pemanfaatan pakan pada pembesaran ikan kakap putih yang didapatkan yakni sebesar 73.6\% yakni termasuk kedalam kategori mendekati baik bagi pertumbuhan ikan kakap putih. Menurut Rayes et al., (2012), nilai efisiensi pemanfaatan pakan yang baik yakni sebesar 76.15\%. Menurut Akbar et al., (2012), efisiensi pakan merupakan jumlah pakan yang masuk dalam sistem pencernaan ikan untuk melangsungkan metabolisme dalam tubuh dan dimanfaatkan untuk pertumbuhan. Beberapa hal yang dapat memengaruhi tingkat efesiensi pakan yakni pada lingkungan hiperosmotik dengan adanya proses penghematan energi yang terutama pada proses osmoregulasi, dan ditambah dengan rasa lapar pada ikan yang dapat membuat respon ikan menjadi cepat dan dalam jumlah yang besar. Menurut Rayes et al., (2013), pada lingkungan yang hiperosmotik, ikan akan menghemat pengeluaran energi terutama untuk proses osmoregulasi, ditambah pula dengan rasa lapar pada ikan. Rasa lapar ini membuat ikan cepat merespon pakan dengan cepat dan dengan jumlah yang besar. Energi dari pakan yang berlebih selanjutnya dialihkan untuk pertumbuhan.

Kualitas air menjadi faktor yang sangat penting dalam keberlangsungan hidup ikan. Nilai parameter kualitas air pada pembesaran ikan kakap putih dalam sistem keramba jaring apung di perairan Lampung tersaji pada Tabel 1

Tabel 1. Hasil Analisis Kualitas Air pada Keramba Jaring Apung

\begin{tabular}{lllcl}
\hline No & Pameter & Satuan & Kisaran Nilai & SNI 01-6493.1-2000 \\
\hline 1 & Salinitas & $\%$ o & $30,4-33,2$ & $15-35$ \\
2 & DO & mg/L & $4,89-5,89$ & $>5$ \\
3 & Suhu & ${ }^{\circ} \mathrm{C}$ & $28,2-29,9$ & $26-32$ \\
4 & pH & - & $7-7,8$ & $7-8,5$ \\
5 & Kecerahan & $\mathrm{m}$ & $9-9,5$ & $>5$ \\
\hline
\end{tabular}

Berdasarkan data pengukuran kualitas air dapat diketahui bahwa hasil pengukuran kualitas air tergolong baik. Nilai pengukuran pH juga tergolong baik yakni 7-7.8 karena masih berada pada batas normal budidaya air laut. Suhu berada pada kisaran $29-29.9^{\circ} \mathrm{C}$. Salinitas berada pada kisaran 30-33 \%o yang masih dapat ditolerir oleh kakap putih. Menurut Hardianti et al., (2016), pH atau derajat keasaman yang baik untuk produksi adalah pH air laut rentang 7-9. Suhu perairan berada pada kisaran $28.6-29.2^{\circ} \mathrm{C}$. Salinitas $31-31.3 \%$ tergolong cukup sesuai untuk kakap putih dewasa. Nilai pengukuran DO yang diperoleh berkisar antara 4,89-5,89, nilai DO untuk budidaya air laut sebaiknya berada diatas $5 \mathrm{mg} / \mathrm{L}$. Hal ini diperkuat oleh Shubhi et al., (2017), yang menyatakan bahwa konsumsi oksigen tiap jenis berbeda-beda, ikan pelagis seperti kakap merah dan kakap putih memerlukan DO yang lebih tinggi dibandingkan ikan demersal. Pada umumnya DO harus berada pada kisaran 5 ppm atau lebih dan tidak boleh kurang dari 4 ppm untuk pelagis atau 3 ppm untuk demersal yang dibudidayakan di KJA.

\section{KESIMPULAN}

Pembesaran ikan kakap putih (Lates calcalifer Bloch, 1790) yang dibudidayakan di perairan Lampung selama 32 hari pembesaran dengan pakan pellet dengan kadar protein 46\%, didapatkan nilai SGR 0,28\%/hari, nilai pertumbuhan bobot mutlak $47 \mathrm{~g}$, dan nilai kelulushidupan 82,5\%. Hasil pengukuran parameter kualitas air meliputi salinitas berkisar 30-33\%o, DO antara 4,89-5,89 mg/L, suhu antara 29-29,9 $\mathrm{C}$, pH antara 7-7,8, kecerahan antara 9-9,5 m. 


\section{DAFTAR PUSTAKA}

Akbar, S., M. Soemarno dan E. Kusnendar. 2012. Pengaruh Pemberian Pakan yang Berbeda terhadap Pertumbuhan Ikan Kerapu Macan (Ephinephelus fuscoguttatus) pada Fase Pendederan di Keramba Jaring Apung (KJA). J. Teknologi Pangan. 1(2): 93-101.

Badrudin., B. Slamet., T. Keast, Dikrurahman., K. B. Kurniawan., S. Mulyono., Sarwono., Setiawan., R. S. Purnama, dan K. Widiada. 2015. Seri Panduan Perikanan Skala Kecil Budidaya Ikan Kakap Putih (Lates calcarifer, Bloch, 1790) di Karamba Jaring Apung dan Tambak. Jakarta, WWF-Indonesia, 30 hlm.

Chen, H.Y. and J.C. Tsai. 1994. Optimally Dietary Protein Level for the Growth of Juvenile Grouper Ephinephelus malabaricus fed semipurified diets. Aquaculture, 119: 265-271.

Cremer, M.C., Z. Jian, and H.P. Lan. 2001. Cage Production of Japanese Sea Bass weaned Trash Fish to Extruded Feed at Sub-market Size Result of Asa/China Feeding Trial 35-01-128. American Soybean association Press. China. 5 pp.

Effendi. 1997. Biologi Perikanan. Yayasan Pustaka Nusatama: Yogyakarta. 163 hlm.

Effendi, H. 2003. Telaah Kualitas Air bagi Pengelolaan Sumber Daya dan. Lingkungan Perairan. Kanisisus: Yogjakarta.

Hardianti, Q., Rusliadi, dan Mulyadi. 2016. Effect of Feeding Made with Different Composition on Growth and Survival Seeds of Barramundi (Lates calcarifer, Bloch). Jurnal Online Mahasiswa. 3(2): 1-10.

Hepher, B. 1988. Nutrition of Pond Fishes. Cambridge University Press. Great Britain. 388p.

Iskandar, R., dan Elrifadah. 2016. Pertumbuhan dan Efisiensi Pakan Ikan Nila (Oreochromis niloticus) yang Diberi Pakan Buatan Berbasis Kiambang. Zira'ah. 40(1): 18-24.

Jaya, Berian, F. Agustriani dan Isnaini. 2013. Laju Pertumbuhan dan Tingkat Kelangsungan Hidup Benih Kakap Putih (Lates calcarifer, Bloch) dengan Pemberian Pakan yang Berbeda. Maspari Journal. 5(1) : 56-63.

Novriadi, R., T. Hermawan., Ibtisam, Dikrurrahman, M. Kadari., M. Herault., V. Fournier., P. Seguin. 2014. Kajian Respons Kekebalan Tubuh dan Performa Pertumbuhan Ikan Kakap Putih Lates calcarifer Bloch melalui Suplementasi Protein Hidrolisis pada Pakan. Jurnal Akuakultur Indonesia. 13(2): 182-191.

Purba, E. P., M. Ilza dan T. Leksono. 2016. Study Penerimaan Konsumen terhadap Steak (Fillet) Ikan Kakap Putih Flavor Asap. Jurnal Online Mahasiswa. 3(2): 1-11. ISSN: 2355-6900.

Rayes, R. D., I. W. Sutresna., N. Diniarti dan A. I. Supii. 2013. Pengaruh Perubahan Salinitas Terhadap Pertumbuhan dan Sintasan Ikan Kakap Putih (Lates calcarifer Bloch). Jurnal Kelautan. 6(1): 47-56.

Shubhi, M. Z. A., Y. S. Kusumadewi dan D. Suswati. 2017. Study of Suitability and Environmental Carrying Capacity for Barramundi (Lates calcarifer, Bloch) Culture in Waters of Lemukutan Island and Penata Besar Island, Bengkayang Region, West Kalimantan. Aquasains, 5(2): 475-487.

SNI. 2000. Produksi Pembesaran Ikan Kakap Putih (Lates calcarifer, Bloch) Kelas Pembesaran. 01-6493.1-2000. Sugiyono. 2010. Metode Penelitian Kuantitatif, Kualitatif dan R\&D. Alfabeta. Bandung.

Yaqin, M.A., Santoso L., dan Saputra S. 2018. Pengaruh Pemberian Pakan dengan Kadar Protein Berbeda terhadap Performa Pertumbuhan Ikan Kakap Putih (Lates calcalifer) di Keramba Jaring Apung. Sains Teknologi Akuakultur, 2(1): 12-19. 